\title{
Interferensi Bahasa Bima Dalam Komunikasi Bahasa Indonesia Di Kelas IX SMPN 1 Sape Kabupaten Bima
}

\author{
Arifuddin \\ Program Studi Pendidikan Sosiologi STKIP Bima \\ Jalan Piere Tendean Kel. Mande Tlp.Fax (0374) 42801, Bima 84191, Indonesia \\ email; arifuddinwise@gmail.com
}

\begin{abstract}
Abstrak
This research concerns with the interference of Bimanese language to Indonesian language communicated by the third grade students of SMPN I Sape Kabupaten Bima. The data is oral language which is spoken by the students and teachers whose their mother language is Bimanese. The result of the research shows that there are three types of the interference which are occurred school: phonological, morphological, semantic and syintax interferences. The interference of Bimanese is not occurred consciously, but it is occurred because there is an effect from daily life so that the element of Bimanese words or sentences is still carried in the communication at the school.
\end{abstract}

Kata Kunci : Interference, Bimanese language, Indonesian language learning. 


\section{Pendahuluan}

Bahasa Indonesia adalah bahasa nasional yang berperan sebagai lingua franca terhadap berbagai keragaman suku bangsa dan bahasa di Indonesia. Ada ratusan suku bangsa dengan latar belakang yang berbeda-beda. Salah satu bentuk keragamannya tercermin dalam dimensi kebahasaan, yaitu keragaman secara multi lingual dalam masyarakat tutur: ada bahasa Indonesia yang digunakan secara luas; ada pula berbagai bahasa daerah yang digunakan oleh masyarakat, baik untuk komunikasi sehari-hari maupun untuk keperluan yang sifatnya kedaerahan.

Dalam masyarakat tutur dengan latar belakang bahasa yang multilingual, anggota-anggota masyarakatnya akan cenderung untuk menggunakan dua bahasa atau lebih, baik sepenuhnya atau sebagian, sesuai dengan kebutuhan (Chaer, 1994:68). Kefasihan seseorang menggunakan dua bahasa (bilingual) atau lebih sangat tergantung kepada kesempatan menggunakan kedua bahasa tersebut. Jika kesempatannya banyak, maka kefasihannya akan bertambah baik, sebaliknya bila sedikit kesempatan maka kefasihannya akan tetap atau bahkan berkurang. Dominasi pemanfaatan kesempatan yang ada memberikan kontribusi bagi kemungkinan munculnya kefasihan bahasa yang digunakan oleh anggota masyarakat. Dengan anggapan yang sama dapat dikatakan, apabila pengunaan bahasa Indonesia lebih dominan dari bahasa daerah, maka yang lancar adalah bahasa Indonesia. Sebaliknya, apabila bahasa daerah yang lebih dominan, maka bahasa Indonesia akan lamban dan bahkan menjadi stagnan.

Bahasa Bima dipakai oleh masyarakat yang tinggal di propinsi Nusa Tenggara Barat (NTB), khususnya di masyarakat yang berada di wilayah Kabupaten Dompu, Kabupaten Bima dan Kota Bima. Bahasa Bima sebagai bahasa daerah mempunyai logat dan dialek yang berbedabeda sesuai dengan wilayah domisili penuturnya. Selain di Propinsi NTB, di Propinsi Nusa Tenggara Timur (NTT) juga terdapat daerah yang dominan masyarakatnya menggunakan bahasa Bima untuk berkomunikasi yakni di daerah Kabupaten Labuan Bajo dan Kabupaten Manggarai. Umumnya masyarakat Labuan Bajo dan Manggarai berasal dari Bima sehingga logat bahasa Bima yang dipakai oleh masyarakat di kedua kabupaten tersebut tidak jauh berbeda dengan logat yang diucapkan oleh penutur bahasa Bima yang berada di wilayah Kabupaten Dompu, Kabupaten Bima dan kota Bima.

Dalam penggunaan bahasa Bima yang dikuasai anak sejak kecil dan terus digunakan dalam kehidupan siswa yang bersekolah sudah tentu berpengaruh pada penggunaan bahasa pada saat mereka mengikuti pelajaran di sekolah. Apalagi anak Sekolah Menengah Pertama yang masih kental dengan bahasa ibunya. Selain itu juga, penduduk yang tinggal di sekitar sekolah mayoritas suku Bima, kemungkinan anak-anak menggunakan bahasa Bima untuk berkomunikasi dalam proses belajar-mengajar di sekolah sangat besar. Chaer (1994: 67) menyebut gejala pemakaian bahasa seperti ini sebagai interferensi bahasa atau biasa dikenal dengan negative transfer. Interferensi bahasa adalah terbawa masuknya unsur bahasa lain dalam bahasa yang sedang digunakan, sehingga tampak adanya penyimpangan kaidah dari bahasa yang sedang digunakan.

Penelitian ini mencoba mendeskripsikan bentuk-bentuk interferensi bahasa Bima dalam komunikasi bahasa Indonesia oleh siswa kelas IX SMPN I Sape Kabupaten Bima. Hasilnya diharapkan dapat dijadikan informasi penting bagi pemerhati bahasa dalam upaya pengembangan dan pembinaan bahasa Indonesia. Selain itu hasil penelitian ini diharapkan dapat memberikan kontribusi untuk bagi siapa saja yang memiliki minat dalam bidang linguistik untuk melakukan penelitian 
lebih jauh mengenai interfensi bahasa daerah terhadap bahasa lain.

\section{Metode Penelitian}

Metode yang digunakan dalam penelitian ini adalah metode deskriptif kualitatif. Datanya adalah bahasa lisan yang dituturkan oleh baik siswa maupun guru di dalam proses belajar-mengajar bahasa Indonesia di kelas. Data tersebut diperoleh dengan teknik simak libat cakap, catat, dan rekam. Data yang terkumpul dianalisis dengan metode padan intralingual dengan teknik hubung banding menyamakan dan membedakan bentukbentuk interferensi (bahasa Bima dengan Indonesia) yang teranalisis. Selain itu digunakan juga metode padan ekstralingual dengan teknik hubungbanding bentuk-bentuk bahasa dengan halhal luar bahasa, misalnya kesepadanan bentuk bahasa yang digunakan dengan penutur, tujuan, dan konteks tuturan.

\section{Hasil Penelitian}

Masuknya bahasa Bima dalam tuturan yang dilakukan siswa dalam pembelajaran bahasa Indonesia di sekolah umumnya terjadi secara spontan, artinya dalam berkomunikasi siswa tidak merancang penuturan kalimat harus menggunakan bahasa Bima. Namun tuturan percakapan dengan bahasa tersebutlah yang sebenarnya dikuasai. Dengan demikian interferensi yang terjadi dikarenakan oleh kebiasaannya bertutur menggunakan bahasa Bima dalam kehidupan sehari-hari.

Setelah diperoleh data penelitian dari tuturan yang dihasilkan siswa dan guru yang berlangsung pada saat proses belajar mengajar, peneliti menemukan bahwa interferensi yang terjadi dalam tuturan siswa dan guru terdapat 4 jenis interferensi yaitu pada tataran fonologi, morfologi, semantik dan sintaksis. Interferensi fonologi dapat dibedakan menjadi: interferensi yang terjadi dalam vokal, diftong dan konsonan. Interferensi morfologi hanya terjadi pada prefiks.
Sedangkan semantik terjadi pada pilihan kata dan frase. Selanjutnya, interferensi sintaksis dapat dilihat pada tataran frasa dan klausa.

\section{Interferensi Fonologis}

Interferensi fonologis adalah kekacauan atau gangguan sistem suatu bahasa yang berhubungan dengan fonem. Interferensi fonologi ini terjadi pada tataran vokal, diftong dan tataran konsonan. Interferensi pada tataran vokal tampak seperti di bawah ini.

(1) mangaku------------mengaku

(2) palisi ------------------polisi

(3) cilaka --------------- celaka

(4) alamari--------------almari

(5) Endonesia ------------Indonesia

Data tersebut memperlihatkan bahwa interferensi fonologi bahasa Bima dalam bahasa Indonesia yang terjadi pada tataran vokal yakni terjadi perubahan vokal [e] dalam bahasa Indonesia menajdi vokal [a] dalam bahasa Bima. Seperti pada kata mangaku terjadi perubahan vokal [e] dengan vokal [a]. Perubahan ini disebut interferensi yang terjadi pada fonem dari bahasa Bima kedalam bahasa Indonesia sebab pola baku bahasa Indonesia adalah "mengaku" bukan mangaku. Kata "polisi" dari bahasa Indonesia, berubah pengucapan dalam bahasa Bima menjadi palisi. Perubahan kata palisi terjadi pada perubahan vokal [o] menjadi vokal [a]. Pada kata "celaka" dari bahasa Indonesia, berubah pengucapan dalam bahasa Bima menjadi cilaka. Perubahan pada kata cilaka terjadi pada perubahan vokal [e] menjadi vokal [i]. Selanjutnya, pada kata alamari terjadi perubahan dengan menambahkan vokal [a] di antara dua rangkaian konsonan [1m]. Penambahan ini disebut interferensi yang terjadi pada fonem dari bahasa Bima ke dalam bahasa Indonesia sebab pola baku bahasa Indonesia adalah "almari" bukan alamari. Demikian juga perubahan pengucapan vokal [i] menjadi vokal [e] pada kata "Indonesia" dalam bahasa Indonesia 
menjadi Endonesia dalam bunyi bahasa Bima.

Interferensi fonologi bahasa Bima dalam bahasa Indonesia terjadi pula pada bidang diftong, misalnya data (6) kalo „kalauee. Dalam hal ini, kata kalo dalam bahasa Bima berekuivalen dengan kata "kalau" dalam bahasa Indonesia yang terdapat diftong [au]. Dalam kata kalo diakhiri vokal [o] namun dalam kata "kalau" diakhiri dengan diftong [au]. Oleh sebab itu, kata "kalau" sudah terinterferensi bahasa Bima menjadi kalo. Kasus ini juga terjadi pada leksikal "pulau" menjadi pulo dan pada leksikal "atau" menjadi ato dalam bahasa Bima.

Interferensi fonologi bahasa Bima dalam bahasa Indonesia juga terjadi pada bidang konsonan yakni terjadi perubahan konsonan dalam bentuk penghilangan bunyi konsonan dan penggantian bunyi konsonan. Hal ini terlihat dari data berikut.

(7) sala --------- salah

(8) musu -------- musuh

(9) langi---------langit

(10) embe -------- ember

(11) pana---------panas

(12) baju ---------baju

Data diatas memperlihatkan bahwa pengucapan kata "salah", "musuh", "langit", "ember" dan "panas" dalam bahasa Indonesia akan mengalami penghilangan fonem konsonan yang terletak pada bagian akhir kata. Perubahannya dapat terlihat penghilangan bunyi [h] pada kata salah sehingga menjadi sala dan musuh menjadi musu dalam pengucapan bahasa Bima. Demikian juga terjadi penghilangan bunyi [t] pada kata langit menjadi langi, penghilangan bunyi [r] pada kata ember menjadi embe, penghilangan bunyi [s] pada kata panas menjadi pana. Kasus seperti ini merupakan interferensi fonologi dalam bidang konsonan sebab terjadi penghilangan bunyi konsonan yang berada di bagian akhir kata. Sedangkan pengucapan kata "baju" dalam bahasa Indonesia akan menjadi baju dalam pengucapan bahasa Bima. Terjadi perubahan pengucapan dari bunyi bilabial bersuara biasa [b] dalam bahasa Indonesia menjadi bunyi bilabial implosif bersuara [ b ] dalam bahasa Bima.

\section{Interferensi Morfologis}

Interferensi morfologi terjadi pada unsur pembentuk kata yang meliputi: prefiks, sufiks, dan konfiks. Dari data yang diperoleh, interferensi morfologi bahasa Bima kedalam bahasa Indonesia hanya teridentifikasi pada prefiks dan sufiks. Hal ini terlihat pada data berikut ini.

(13) pedagang -- pa- + daga $(-n g)=$ padaga

(14) perampok---pa- + rampo $(-\mathrm{k})=$ parampo

(15) rumahnya-- $(-\mathrm{r})$ uma $(-\mathrm{h})+-$ na $=$ umana

(16) jelaskan--- jelas + ka-ja = kajelasja

(17) dirapikan----kasi- + rapi = kasirapi

\section{Interferensi Semantik}

Berdasarkan hasil analisis, interferensi semantik yang terjadi pada keterampilan ber-bicara siswa diakibatkan adanya leksikal baha-sa Indonesia yang konteks penggunaanya tidak tepat. Penggunaan leksikal bahasa Indonesia ini menyebabkan kesalahan kebahasaan dan kesalahan makna karena pemaknaannya dipengaruhi oleh leksikal bahasa Bima. Hal tersebut yang menyebabkan interferensi pada tataran leksikal, sebagaimana yang terlihat pada data di bawah ini.

(18) Jangan panas dulu, pak! Bapak belum tahu masalahnya.

(19) Hujannya sudah diam. Ayo kita berangkat sekarang!

(20) Saya ikut kamu aja. Sampai perempatan Desa Bugis, simpan saya di sana!

(21) Kenapa kamu simpan saya?

(22) + Ani: Andi itu alamatnya di mana?

- Farid : Apa dekat Masjid Raya itu, bu.

Dalam komunikasi bahasa Indonesia sering kali terjadi kesalahan penempatan kata secara kontekstual. Leksikal bahasa Bima pana (18) memiliki padanan makna 
dengan leksikal panas dalam bahasa Indonesia. Ada dua konteks kenapa kata pana muncul. Pertama, pana menunjukan bahwa seseorang sedang emosional (cenderung terjadi kontak secara fisik). Kedua, pana berhubungan dengan keadaan panas suatu benda atau semacamnya. Tetapi pemakaiannya sering salah. Kesalahan terjadi seolah-olah kata pana berlaku untuk semua konteks. Penggunaan leksikal panas diatas dianggap salah karena panas yang dimaksud berhubunngan dengan panas secara emosional. Sehingga padanan kalimat yang tepat adalah, jangan emosi dulu pak, bapak belum tahu masalahnya. Panas mengalami interferensi oleh bahasa Bima. Kemudian kata diam (19) juga mengalami interferensi. Kata diam lebih berhubungan dengan keadaan yang sunyi. Dalam kaitannya dengan hujan, seharusnya menggunakan diksi reda sehingga penggunaan yang tepat pada konteks tuturan diatas adalah hujan sudah reda, ayo kita berangkat sekarang. Selanjutnya, kata simpan (20). Simpan pada tuturan diatas merupakan padanan dari makna wi' $i$ dalam bahasa Bima. Tetapi terjadi kesalahan ketika dialihkan kedalam bahasa target. Padanan yang benar adalah tinggalkan/turunkan, sehingga kalimat baku yang dapat diterima adalah Saya ikut kamu aja. Sampai perempatan Desa Bugis, turunkan saya di sana. Demikian juga yang terjadi pada tuturan kata simpan (21). Simpan dalam konteks kata diatas dihubungkan dengan wi' $i$, dalam bahasa Indonesia yang artinya menuduh. Kalau disesuaikan padanannya maka tuturan kalimat kenapa kamu simpan saya? menjadi kenapa kamu menuduh saya?. Kesalahan atau interferensi juga terjadi pada data (22). Kata apa adalah makna dari kata au dalam bahasa Bima. Tetapi penggunaan kata $a u$ tidak harus diterjemahkan dengan kata $a p a$, karena maknanya bisa menjadi rancu. Padanan yang tepat dapat disederhanakan menjadi dekat masjid raya itu, bu! Kecuali au itu berbentuk pronominal question, padanannya dengan kata apa dapat diterima.

\section{Interferensi Sintaksis}

Interferensi bahasa Bima dalam bahasa Indonesia terjadi pula dalam bidang sintaksis yakni pada tataran frasa dan klausa. Interferensi pada tataran frasa terlihat dalam peristiwa tutur yang berikut ini.

(23) Janganja ribut ni! "mohon jangan ribut!

(24) + Rita: Emangnya kamu mengerti IPA?

- Rio: de mengerti saya ni IPA. matematika" "ya saya mengerti

(25) + Guru: kamu, pilih warna apa?

- Siswa: apa yang merah tu.

"yang merah"

(26) + Mardia: Rina, itu buku siapa?

- Rina : yang mana?

+ Mardia : itu yang diatas meja.

- Rina : oh itu. Buku la Syarif. "buku milik Syarif"

\section{Penyebab Terjadinya Interferensi}

Kasus interferensi bahasa Bima kedalam bahasa Indonesia sering terjadi dalam komunikasi sehari-hari siswa dan guru di sekolah SMPN I Sape Kabupaten Bima. Keadaan ini terjadi bukan karena disengaja oleh siswa dengan maksud untuk mempermudah penyampaian buah pikirannya, tetapi terjadi karena penguasaan sistem bahasa pertama (bahasa Bima) mereka yang lebih tinggi dari kemampuan mereka bertutur dengan bahasa Indonesia. Penguasaan bahasa pertama yang lebih tinggi oleh siswa menyebabkan mereka terbiasa berbicara dengan bahasa tersebut, dan menjadi sebab mengapa bahasa Bima banyak terbawa ke dalam komunikasi bahasa Indonesia. Selain itu, Interferensi bahasa Bima dalam proses belajar mengajar juga terjadi karena kebiasaan mereka yang dominan menggunakan bahasa Bima dalam lingkungan mereka sehari-hari diluar sekolah, sehingga kebiasaan tersebut 
terbawa dalam tuturan bahasa Indonesia yang bukan merupakan bahasa keseharian mereka. Akibatnya, kemampuan mereka untuk menggunakan bahasa Indonesia sulit berkembang bahkan menurun.

Hasil penelitian menunjukkan bahwa interaksi antar guru dengan murid tidak secara dominan dilakukan dengan menggunakan bahasa Indonesia. Baik guru maupun siswa cenderung menggunakan bahasa Bima pada saat mereka seharusnya bertutur dengan bahasa Indonesia. Penggunaan bahasa Indonesia dalam komunikasi hanya dalam porsi yang kecil karena guru kurang tegas mengenai pilihan bahasa yang tepat dalam komunikasi dunia pembelajaran.

Akumulasi dari keadaan dalam peristiwa tutur tersebut diatas membuat kemampuan bahasa Indonesia siswa tidak berkembang dengan baik, karena mereka selalu menggunakan bahasa Bima dalam berkomunikasi baik di rumah maupun di sekolah. Oleh karena itu secara logis dapat dikatakan, gaya dan kemampuan komunikasi siswa kepada guru pada saat proses belajar mengajar masih sangat dipengaruhi oleh bahasa Bima. Hal tersebut terungkap dalam data-data hasil penelitian yang sudah dipaparkan diatas, yang mana pada setiap berkomunikasi, kata dan tata bahasa serta tuturan yang bernuansa bahasa Bima terbawa kedalam bahasa Indonesia. Keadaan semacam ini menunjukan kemampuan mereka berbahasa Indonesia rendah. Di samping itu, berdasarkan jawaban siswa yang diperoleh pada saat melakukan wawancara, interferensi bahasa Bima yang terjadi pada saat proses belajar mengajar dikarenakan 2 hal : 1) Adanya unsur tidak sengaja. Siswa mengucapkan kata tersebut bukan karena tidak mengerti padanan kata bahasa Indonesia, tapi karena komunikasinya meluncur secara spontan akibat terbiasa dalam bahasa Bima. Dengan kata lain ada transfer kata secara otomatis akibat kebiasaan pembelajar bahasa; 2) siswa tidak mengetahui kosa kata atau struktur kalimat bahasa Bima yang memiliki padanan dengan bahasa Indonesia. Untuk memudahkan komunikasi, siswa memilih menggunakan kosa kata dan klausa bahasa Bima meskipun dengan makna dan konteks yang tidak tepat. Kenyataan semacam ini semakin memberi peluang terjadinya interferensi.

\section{Kesimpulan}

Berdasarkan pada data dan uraian analisis yang telah disampaikan sebelumnya, beberapa kesimpulan dapat dikemukakan bahwa bentuk interferensi bahasa Bima dalam pembelajaran bahasa Indonesia meliputi aspek fonologi, morfologi, semantik dan sintaksis. Aspek fonologi meliputi: perubahan bunyi vokal [e] dalam bahasa Indoneisa menjadi vokal [a], vokal [o] dalam bahasa Indonesia menjadi vokal [a] dalam bahasa Bima, dan vokal [e] dalam bahasa Indonesia menjadi vokal [i] dalam bahasa Bima, dan vokal [i] dalam bahasa Indonesia menjadi vokal [e] dalam bahasa Bima; pada tataran diftong juga terjadi interferensi bahasa Bima pada bunyi diftong [au] dalam bahasa Indonesia menjadi [o] dalam bahasa Bima. Pada tataran konsonan juga terjadi perubahan bunyi konsonan yang terjadi pada penghilangan fonem konsonan $/ \mathrm{h} /, \mathrm{t} / \mathrm{/} / \mathrm{r} /$, /s/ yang terletak pada bagian akhir kata. Penggantian fonem terjadi pada fonem $/ \mathrm{b} /$ dalam bahasa Indonesia menjadi fonem / $\underline{b} /$ dalam bahasa Bima. Pada aspek morfologis terdapat prefiks /pa/ dan /kasi/, sufiks /na/ dan konfiks /ka-ja/. Dan selanjutnya bentuk interferensi yang ditemukan dalam aspek semantik adalah kesalahan konteks penggunaan leksikal simpan, diam, apa dan panas. Kemudian pada aspek sintaksis data menunjukan adanya serapan partikel $n i$, de-ni, dan demonstratif artikel la.

Interferensi terjadi karena peran bahasa Bima lebih dominan daripada bahasa Indonesia. Siswa dan guru cenderung berkomunikasi menggunakan bahasa Bima 
baik di sekolah maupun dalam kehidupan sehari-hari diluar sekolah. Akibatnya bahasa Indonesia sebagai bahasa pengantar pendidikan dalam proses belajar mengajar megalami kehilangan fungsinya di sekolah. Sehingga pada tataran yang paling praksis, siswa kesulitan berkomunikasi dalam bahasa Indonesia secara baik dan benar, baik dalam aspek fonologis, morfologis, semantik dan sintak.

\section{Daftar Pustaka}

Abdulhayi. 1985. Interferensi Gramatikal Bahasa Indonesia dalam Bahasa Jawa. Jakarta: New aqua Perss.

Chaer, A. 2004. Sosiolinguistik. Jakarta: Rineka cipta

Hakim, Z. 1999. Tipe Semantik Bahasa Makassar. Jakarta: Depdikbud.

Mustakim, 1994. Interferensi Bahasa Jawa dalam Surat Kabar Berbahasa Indonesia. Jakarta: Depdikbud.

Rindjin, K, dkk. 1981. Interferensi Gramatikal Bahasa Bali dalam Pemakaian Bahasa Indonesia Murid Sekolah Dasar di Bali. Jakarta: Pusat Pembinaan dan Pengembangan Bahasa.

Tarigan, DJ. 1997. Pendidikan Bahasa dan Sastra Indonesia di Kelas Rendah. Jakarta: Depdikbud. Universitas Terbuka.

Tarigan, H.G. 1990. Pengajaran Analisis Kesalahan Berbahasa. Bandung: Angkasa Bandung. 